\title{
A Bibliometric Analysis Visualization of Translation Education from 2011 to 2020
}

\author{
Yuting Yan \\ Hunan Institute of Technology, Hengyang, China \\ Email: yanyuting@hnit.edu.cn
}

How to cite this paper: Yan, Y.T. (2021) A Bibliometric Analysis Visualization of Translation Education from 2011 to 2020. Open Access Library Journal, 8: e7767. https://doi.org/10.4236/oalib.1107767

Received: July 16, 2021

Accepted: August 1, 2021

Published: August 4, 2021

Copyright $\odot 2021$ by author(s) and Open Access Library Inc.

This work is licensed under the Creative Commons Attribution International License (CC BY 4.0).

http://creativecommons.org/licenses/by/4.0/

\section{(c) (i) Open Access}

\begin{abstract}
The purpose of this study is to reveal the tendency of research in the field of translation education with the analysis of scientific collaboration network, keywords co-occurrence and citations by taking into consideration of publication output, author, institution, country, keyword and citations. The Web of Science core collection database was used as the data source, and 652 recordings published from 2011 to 2020 were retrieved. VOSViewer and CiteSpace were applied for bibliometric analysis. The results were: 1) the publication increased with fluctuation from 2011 to 2020;2) Olalla-Soler, Christian was the most productive author, and Univ Autonoma Barcelona was the most productive institution; 3) translation, language, working memory, and competence stand out in the research of translation education; 4) translation practice, implicit teaching, translation competence are the trending topics; 5) Kelly, Dorothy was the most influential author, Interpreter and Translator Trainer was the most influential journal, and "The Acquisition of Translation Competence. Competencies, Tasks, and Assessment in Translator Training" was the most cited article.
\end{abstract}

\section{Subject Areas}

Linguistics

\section{Keywords}

Bibliometric Analysis, Visualization, Web of Science, Translation Education, Translator Training

\section{Introduction}

With more programs training translators and interpreters, the importance of translation education is recognized. Taking China as an example, up to 2019, 
281 universities established Bachelor of Translation and Interpretation (BTI) programs [1]. Research on translation education covers a wide range of topics such as translation competence [2] [3], machine translation [4] [5], motivation improvement [6] [7], ethics [8] [9], pedagogy [10] [11], translation technologies [12] [13]. Two kinds of software, VOSViewer (1.6.16) [14] and CiteSpace (5.7.R2)

[15] were used in this study.

This paper is organized as follows. First, the data collection and methods are introduced. Second, the bibliometric analysis is presented from six aspects, namely, publication outputs, scientific collaboration network, the keywords and trend topics, most cited authors, most cited publications, and most cited references. Lastly, come conclusions and discussions will be proposed.

\section{Methods}

\subsection{Data Collection}

Web of Science (WoS) Core Collection data based was used in our study. We set the search query as: TS = "translation training" OR TS = "translator training" OR TS = "interpreting training" OR TS = "interpreter training" OR TS = "translation teaching" OR TS = "interpreting teaching" OR TS = "translation curriculum" OR TS = "translation classrooms" OR TS = "translation students" OR TS = "translation teachers" OR TS = "translation pedagogy" OR TS = "interpreting pedagogy"; language is English; document type is Article or Review; Time ranges from 2011 to 2020.652 records were retrieved.

\subsection{Data Analysis}

In this study the number of publications per year, co-authorship network, network of co-authors' institutions, network of co-authors' countries, co-occurring keywords, document co-citation network, author co-citation network, and journal co-citation network were analyzed. The tools used were CiteSpace and VOSViewer. In this study, we reclassified Taiwan, Hong Kong and Macao into China, England, Scotland and Wales into UK.

\section{Results}

\subsection{Analysis of Output}

From 2011 to 2020, there were in total of 652 publications. As shown in Figure 1 , the number of publications fluctuated. The number reached a low point in 2013 with 25 contributions, and a high point in 2019 with 105 contributions. In general, the number of publications per year increases with fluctuation, which indicated a continuous interest in the field of translation education.

\subsection{Scientific Collaboration Network Analysis}

We analyzed the scientific collaboration network at three levels: author, institution, and country. We used VOSViewer to do the analysis. 1051 authors contributed in the field of translation education. We only chose authors with more 


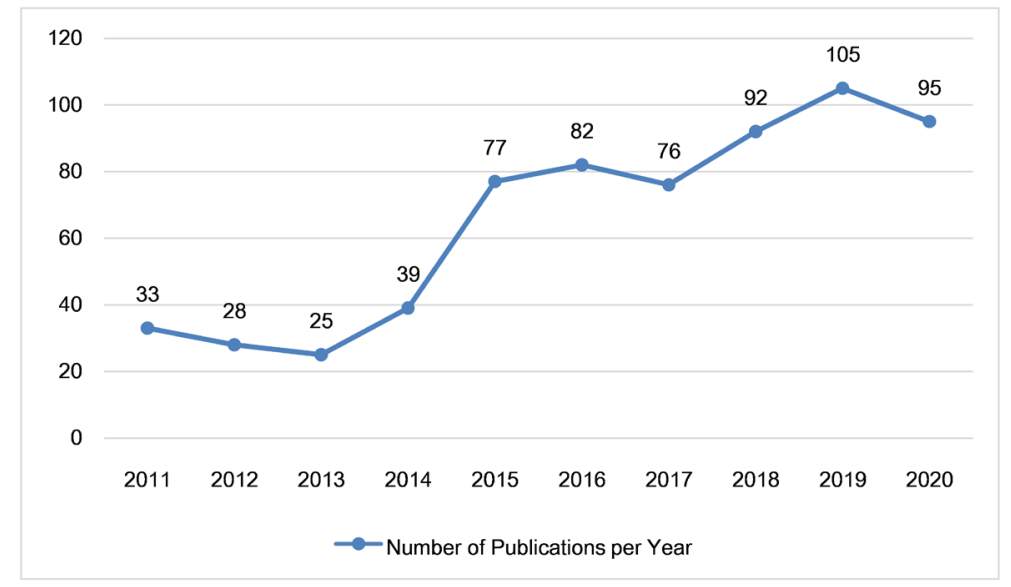

Figure 1. The number of publications per year.

than 3 publications. After the program finished, we got the co-authorship network shown in Figure 2. The larger the node was, the more publications an author contributed. Different colors meant these authors were in different clusters. From Figure 2, we could see there were few links among authors, which meant weak collaborations among authors. There were three major clusters. The first one consisted of Nour, Soudabeh, Stengers, Helene and Struys, Esli. The second one included Galan-Manas, Anabel, Hurtado Albir, Amparo and Olalla-Soler, Christian. The last one consisted of Pan, Jun, Wang, Honghua and Yan, Jackie Xiu. In terms of the number of publications, shown in Table 1, Olalla-Soler, Christian ranked the first with 8 documents. Dong, Yanping was the second with 7 documents. Lee, Jieun was the third with 6 documents.

The next was to analyze the co-authorship network at the institution level. There were in total 558 institutions involved. We set the minimum document as 5, and 40 met the threshold. Density visualization was shown in Figure 3. The more documents were, the closer the color was to yellow. Together with Table 2, Univ Autonoma Barcelona ranked the first with 22 documents, Guangdong Univ Foreign Studies the second with 16 documents, Islamic Azad Univ the third with 15 documents. From the results we could conclude that the above three universities focus on the research of translation education.

Thirdly we analyzed the country co-authorship network. There were in total 66 countries contributing to the field of translation education. We set the minimum number of documents as 5, then 33 met the threshold, shown in Figure 4. The larger the node was, the more documents a country contributed. The same color indicated the countries belong to the same cluster. From Figure 4, we can see China, Spain, the UK and the USA contribute more. China collaborated with UK, Japan, Ireland, and Australia. Spain collaborated with Russia, Saudi Arabia, Slovenia and Switzerland. The USA collaborated with Jordan and Ukraine.

\subsection{The Keywords Analysis and Trend Topics}

A total of 2579 different keywords were used in 652 articles in the field of 
Vandepitte, Sonia

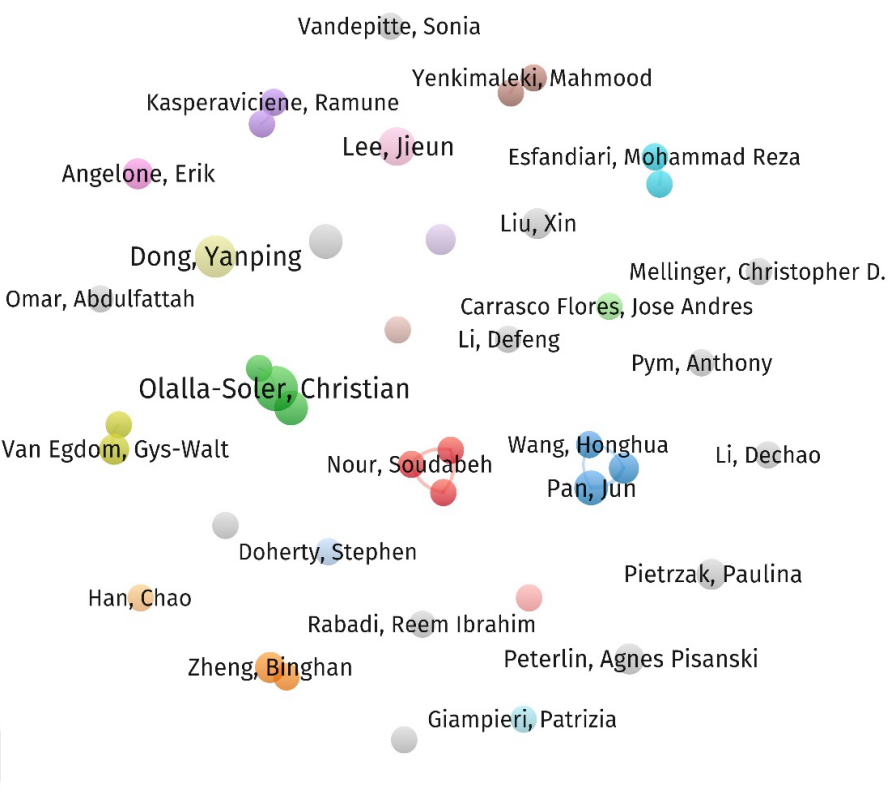

Figure 2. Co-authorship network.

Table 1. Top 5 most productive authors.

\begin{tabular}{cccccc}
\hline Rank & Documents & Citations & Author & Institution & Country \\
\hline 1 & 8 & 22 & Olalla-Soler, Christian & Univ Bologna & Italy \\
2 & 7 & 66 & Dong, Yanping & Zhejiang Univ & China \\
3 & 6 & 33 & Lee, Jieun & Ewha Womans Univ & South Korea \\
4 & 5 & 28 & Galan-Manas, Anabel Univ Autonoma Barcelona & Spain \\
5 & 5 & 18 & Li, Xiangdong & Xi'an Int Studies Univ & China \\
\hline
\end{tabular}

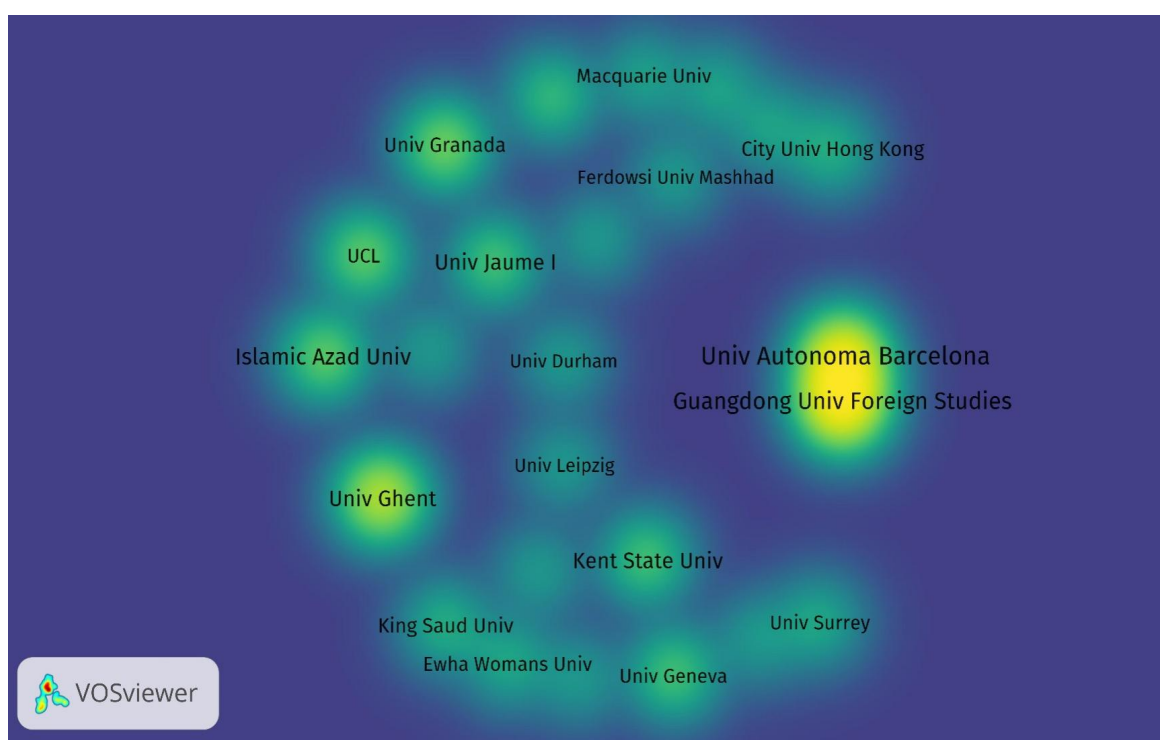

Figure 3. Institution co-authorship network. 
Table 2. Top 5 most productive institutions.

\begin{tabular}{ccccc}
\hline Rank & Institution & Documents & Citations & Country \\
\hline 1 & Univ Autonoma Barcelona & 22 & 98 & Spain \\
2 & Guangdong Univ Foreign Studies & 16 & 75 & China \\
3 & Islamic Azad Univ & 15 & 6 & Iran \\
4 & Kent State Univ & 12 & 84 & USA \\
5 & Univ Ghent & 12 & 82 & Belgium \\
\hline
\end{tabular}

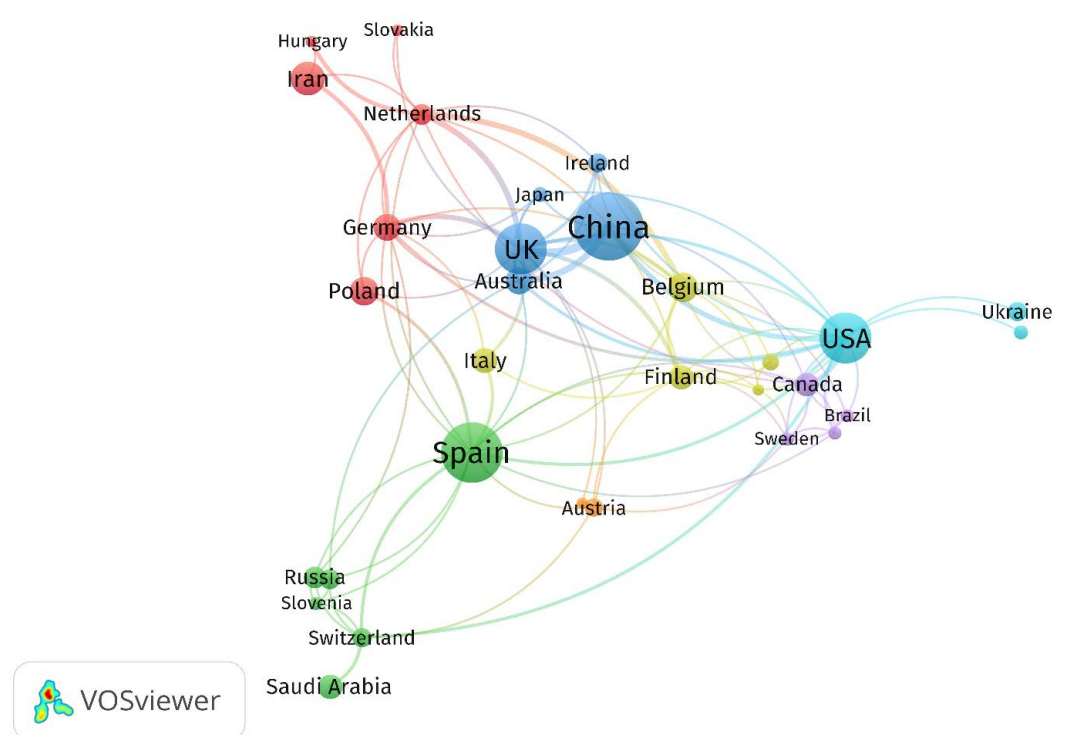

Figure 4. Country co-authorship network.

translation education. We excluded the "translation training", "translator training", "interpreting training", "interpreter training", "translation teaching", "interpreting teaching", "translation curriculum", "translation classrooms", "translation students", "translation teachers", "translation pedagogy" and "interpreting pedagogy", since they were the keywords used in the search query. In the co-occurring analysis of keywords, we set the minimum occurrence as 5, then 98 met the threshold. These keywords formed 7 clusters. The cluster of keywords can help us find the relative topics.

As seen in Figure 5, the largest cluster was in red with 22 keywords, such as communication, education, consecutive interpreting, ethics, and impact. The second cluster was in green with 18 keywords, including language, interpreting, working memory, sight translation and individual differences. The third was in blue with 17 keywords, such as translation competence, intercultural competence, competence, legal translation and audiovisual translation. In terms of total link strength larger than 30, translation, English were in the yellow cluster; language, working memory, interpreting, cognitive control were in the green cluster; competence was in the dark blue cluster; performance, students were in the light blue cluster; machine translation and post-editing were in the purple cluster. 


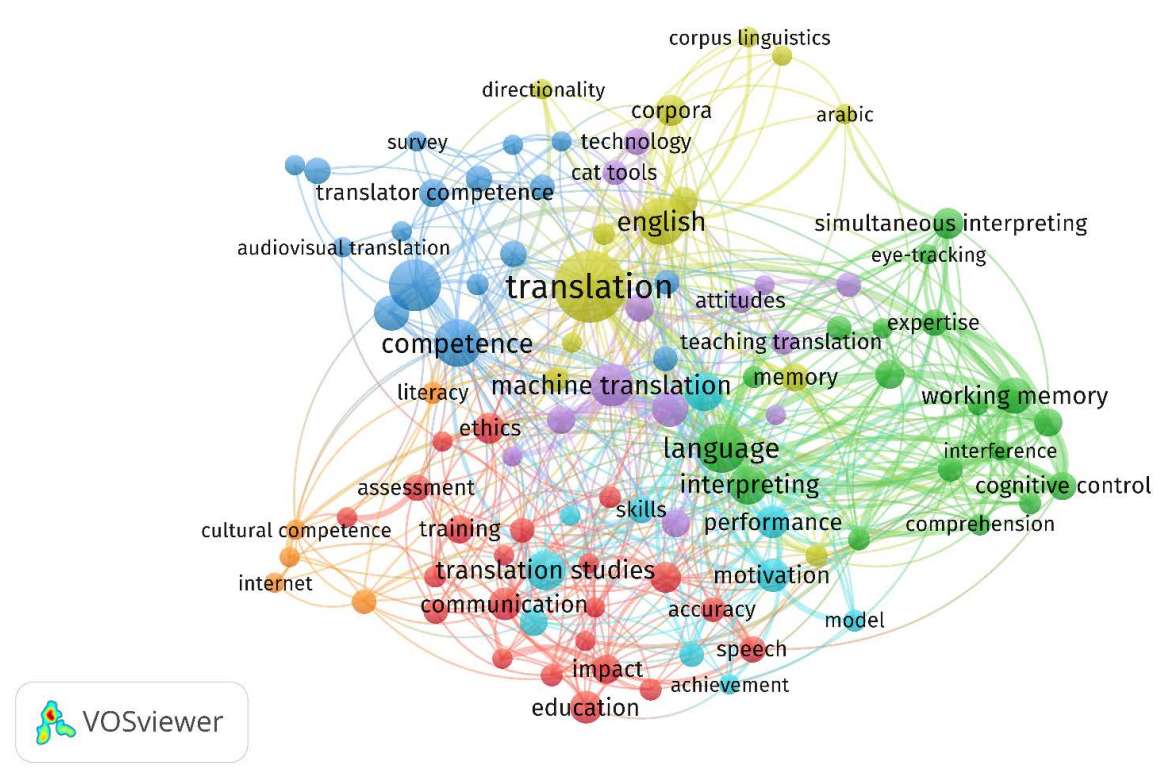

Figure 5. Keyword co-occurrence network.

These findings showed that the importance of translation education lies in translation, language, working memory, competence, interpreting, English, performance, machine translation, students, cognitive control, and post-editing.

The overlay visualization map of keyword co-occurrence was shown in Figure 6. A color bar was shown in the bottom of the map indicating different years. The colors ranged from blue (2011) to green to yellow (2020). Therefore, Figure 6 can help us identify the trend research topics. From Figure 6, we can see in the field of translation education, the keywords such as competence, machine translation, working memory, post-editing, eye-tracking, individual-differences, experience, interference, computer-assisted translation, feedback, CAT tools, directionality, and medical translation have stood out in recent years. This result suggested that scholars have to research on the mentioned topics. In order to strengthen this result, co-occurring keyword analysis was conducted using CiteSpace. Keyword timeline view map was generated in Figure 7. We mainly focused on the year 2019 and 2020. We can see in these two years, deep learning, directionality, explicit teaching, pronunciation, translation quality, medical translation, eye-tracking, simultaneous interpreting, reliability, system, literacy, neural machine translation, translation process research, program, market, terminology, academic writing, corpus analysis, $2^{\text {nd }}$ language proficiency, language control, interference, physical ergonomics, educational ergonomics, validation and Google translate have become the new topics.

\subsection{Most Cited Authors}

We conducted the author co-citation analysis to find the most influential ones. It was observed that 108 authors met the threshold of at least 20 citations. The top 15 authors with highest TLS were listed in Table 3. Kiraly, Don was the most influential author in terms of both citations and TLS. Pym, Anthony ranked the 


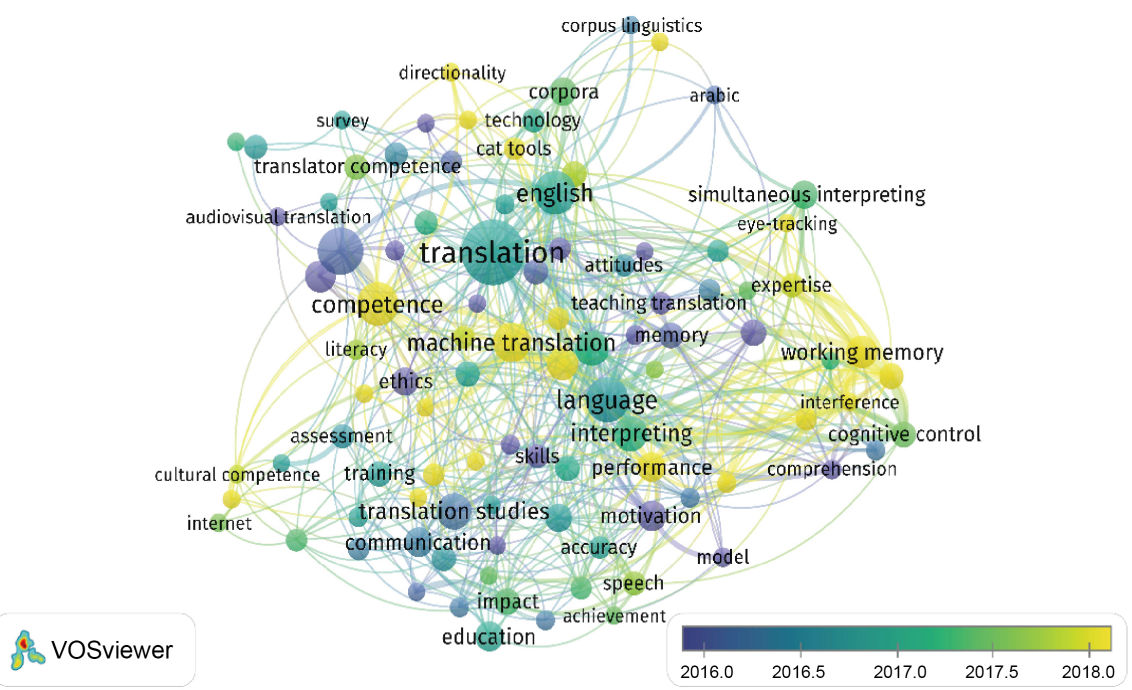

Figure 6. The overlay visualization of keyword co-occurrence network.

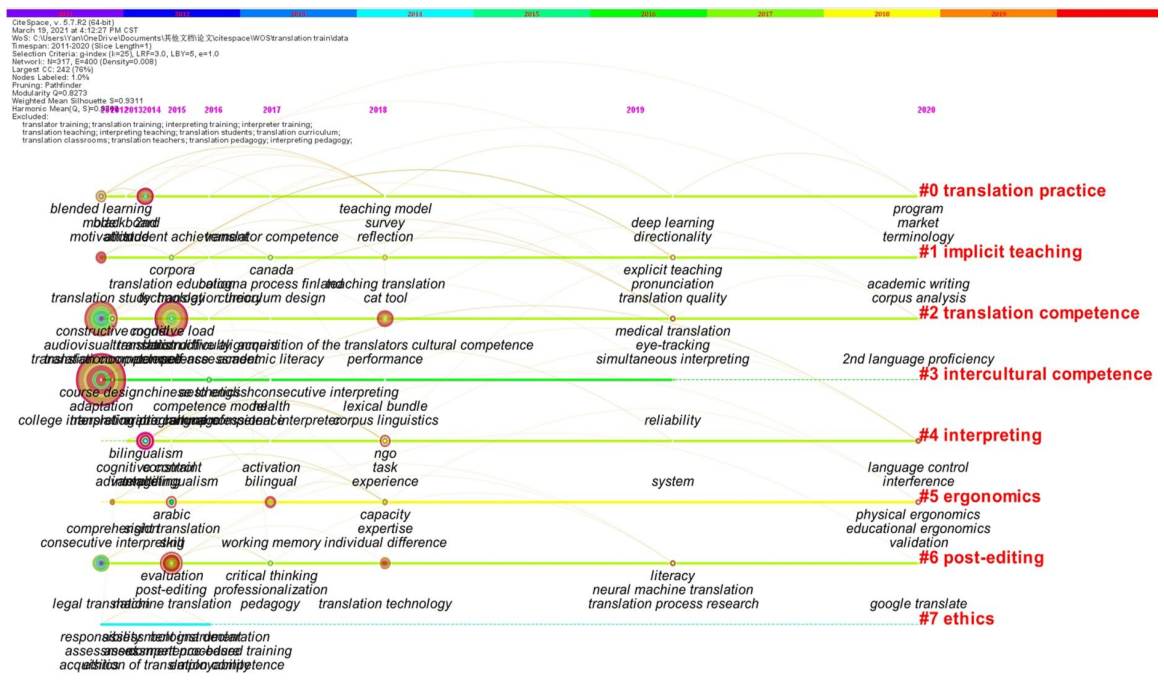

Figure 7. Co-occurring keyword timeline view.

second and Kelly, Dorothy the third in terms of both citations and TLS. In terms of TLS, Beeby, Allison ranked the fourth, while in terms of citations Gile, Daniel was the fourth. Among the 15 most influential authors, four was in Spain; two were in Austria. This result can cast light on researchers newly into the field of translation education.

\subsection{Most Cited Publications}

Among 10051 publications, 36 stood out with at least 50 citations. Top 15 with strongest TLS were listed in Table 4. From Table 4, we can see in terms of TLS, Interpreter and Translator Trainer ranked the first. While in terms of total citations, the first was Meta. Among the 15 publications, 13 were journals, accounting for $87 \%$. Only 2 were books. If researchers want to publish their articles, Interpreter and Translator Trainer and Meta could be their good choices. 
Table 3. Most influential authors.

\begin{tabular}{|c|c|c|c|c|c|}
\hline Rank & Author & Country & University & Citations & TLS \\
\hline 1 & Kiraly, D & Germany & University Mainz & 247 & 2630 \\
\hline 2 & Pym, A & Spain & Universitat Rovira I Virgili & 172 & 1716 \\
\hline 3 & Kelly, D & Spain & Granada University & 137 & 1676 \\
\hline 4 & Beeby, A & Spain & Autonomous University of Barcelona & 122 & 1662 \\
\hline 5 & Gile, D & France & Université Sorbonne Nouvelle-Paris 3 & 135 & 1514 \\
\hline 6 & Albir, Ah & Spain & Autonomous University of Barcelona & 102 & 1432 \\
\hline 7 & Nord, C & South Africa & University of the Free State & 97 & 1344 \\
\hline 8 & Baker, M & UK & University of Manchester & 131 & 1299 \\
\hline 9 & Alves, F & Brazil & Universidade Federal de Minas Gerais & 84 & 1125 \\
\hline 10 & Pochhacker, F & Austria & University of Vienna & 83 & 1047 \\
\hline 11 & Gopferich, S & Austria & University of Graz & 58 & 787 \\
\hline 12 & Colina, S & USA & University of Arizona & 37 & 708 \\
\hline 13 & Bowker, L & Canada & University of Ottawa & 76 & 655 \\
\hline 14 & Schaffner, C & UK & Aston University & 45 & 635 \\
\hline 15 & Toury, G & Israel & Tel Aviv University & 50 & 593 \\
\hline
\end{tabular}

Table 4. Most influential publications.

\begin{tabular}{|c|c|c|c|c|c|}
\hline Rank & Publication & TLS & Citations & Type & Publisher \\
\hline 1 & Interpreter and Translator Trainer & 14898 & 484 & Journal & Taylor \& Francis \\
\hline 2 & Meta & 14092 & 655 & Journal & Presses Univ Montreal \\
\hline 3 & Interpreting & 13665 & 388 & Journal & John Benjamins \\
\hline 4 & Target & 7188 & 231 & Journal & John Benjamins \\
\hline 5 & Perspectives & 5936 & 183 & Journal & Taylor \& Francis \\
\hline 6 & Interpreters Newsletter & 5825 & 163 & Journal & EUT \\
\hline 7 & Babel & 4768 & 122 & Journal & John Benjamins \\
\hline 8 & Benjamins Translation Library & 4564 & 262 & Book series & John Benjamins \\
\hline 9 & Translation and Interpreting Studies & 3776 & 78 & Journal & John Benjamins \\
\hline 10 & International Journal of Interpreter Education & 3704 & 36 & Journal & $\begin{array}{c}\text { Conference of interpreter } \\
\text { trainers }\end{array}$ \\
\hline 11 & Translator & 3282 & 153 & Journal & Taylor \& Francis \\
\hline 12 & Journal of Specialised Translation & 2726 & 190 & Journal & Roehampton Univ \\
\hline 13 & Across Languages and Cultures & 2391 & 83 & Journal & Akadémiai Kiadó \\
\hline 14 & Bilingualism & 1889 & 80 & Journal & Cambridge University \\
\hline 15 & Routledge Encyclopedia of Translation Studies & 1678 & 87 & Book & Routledge \\
\hline
\end{tabular}




\subsection{Most Cited References}

To recognize core references in the field of translation education, it is necessary to focus on the frequency of citations. We used CiteSpace to detect the most cited references. As shown in Table 5, the top 1 most cited reference was that of Amparo Hurtado Albir "The acquisition of translation competence: competences, tasks, and assessment in translator training" [16]. In this paper, examples of how to design translator training curriculums were provided. The second was that of Laura Babcock "Are simultaneous interpreters expert bilinguals, unique bilinguals, or both?” [17]. This paper found interpreters did not show bilingual benefits as previous studies suggested, but they appeared to possess larger verbal and spatial memory spans. The third was that of Federico Gaspari "A survey of machine translation competencies: Insights for translation technology educators and practitioners" [18].

Table 5. Top 15 most cited references.

\begin{tabular}{|c|c|c|c|c|c|}
\hline Rank & Title & First Author & Source & Year & Citations \\
\hline 1 & $\begin{array}{c}\text { The Acquisition of Translation Competence. Competences, } \\
\text { Tasks, and Assessment in Translator Training }\end{array}$ & Albir, AH & Meta & 2015 & 13 \\
\hline 2 & $\begin{array}{l}\text { Are simultaneous interpreters expert bilinguals, unique } \\
\text { bilinguals, or both? }\end{array}$ & Babcock, L & Bilingualism & 2017 & 10 \\
\hline 3 & $\begin{array}{l}\text { A survey of machine translation competences: Insights for } \\
\text { translation technology educators and practitioners }\end{array}$ & Gaspari, F & Perspectives & 2015 & 10 \\
\hline 4 & $\begin{array}{l}\text { Factors contributing to individual differences in the } \\
\text { development of consecutive interpreting competence } \\
\text { for beginner student interpreters }\end{array}$ & Cai, RD & $\begin{array}{l}\text { The Interpreter and } \\
\text { Translator Trainer }\end{array}$ & 2015 & 9 \\
\hline 5 & $\begin{array}{c}\text { Simultaneous interpretation selectively influences working } \\
\text { memory and attentional networks }\end{array}$ & Morales, J & Acta psychologica & 2015 & 9 \\
\hline 6 & $\begin{array}{l}\text { Situated learning in translator and interpreter training: } \\
\text { bridging research and good practice }\end{array}$ & $\begin{array}{l}\text { Gonzalez-Davies, } \\
\text { M }\end{array}$ & $\begin{array}{l}\text { The Interpreter and } \\
\text { Translator Trainer }\end{array}$ & 2016 & 8 \\
\hline 7 & $\begin{array}{c}\text { Classes in translating and interpreting produce differential } \\
\text { gains in switching and updating }\end{array}$ & Dong, YP & $\begin{array}{l}\text { Frontiers in } \\
\text { Psychology }\end{array}$ & 2016 & 8 \\
\hline 8 & $\begin{array}{l}\text { Basic concepts and models for interpreter and translator } \\
\text { training }\end{array}$ & Gile, D & Book & 2009 & 7 \\
\hline 9 & $\begin{array}{l}\text { Towards authentic experiential learning in translator } \\
\text { education }\end{array}$ & Kiraly, D & Book & 2016 & 6 \\
\hline 10 & $\begin{array}{l}\text { Quality in professional translation: assessment and } \\
\text { improvement }\end{array}$ & Drugan Joanna & Book & 2013 & 6 \\
\hline 11 & $\begin{array}{l}\text { Growing a project-based translation pedagogy: A fractal } \\
\text { perspective }\end{array}$ & Kiraly, D & Meta & 2012 & 6 \\
\hline 12 & $\begin{array}{l}\text { Statistical machine translation in the translation curriculum: } \\
\text { Overcoming obstacles and empowering translators }\end{array}$ & Kenny, D & $\begin{array}{l}\text { The Interpreter and } \\
\text { translator trainer }\end{array}$ & 2014 & 6 \\
\hline 13 & Translation skill-sets in a machine-translation age & Pym A & Meta & 2013 & 5 \\
\hline 14 & Competence assessment procedures in translator training & Galán-Mañas A & $\begin{array}{l}\text { The Interpreter and } \\
\text { Translator Trainer }\end{array}$ & 2015 & 5 \\
\hline 15 & $\begin{array}{l}\text { Dialogue interpreting as intercultural mediation: } \\
\text { Interpreters' use of upgrading moves in parent-teacher } \\
\text { meetings }\end{array}$ & Davitti E & Interpreting & 2013 & 5 \\
\hline
\end{tabular}


Among the 15 references, four focused on interpreting. Babcock and Vallesi [17] found interpreters did not show bilingual benefits as previous studies suggested, but they appeared to possess larger verbal and spatial memory spans. Their paper was from a cognitive way. Cai, Dong, Zhao and Lin [19] investigated what competencies impacted beginner student interpreters most in consecutive interpreting. Morales, Padilla, Gomez-Ariza and Bajo [20] conducted experiments to show the transfer of simultaneous interpreting experience was "specific to the cognitive processes more closely involved in the interpreting tasks". Davitti [21] studied dialogue interpreting.

Three focused on machine translation. Gaspari, Almaghout and Doherty [18] conducted surveys to show "an improvement in quality assessment methods, tools, and training” were strongly needed. Kenny and Doherty [22] argued for “a holistic approach to the integration of Statistical Machine Translation into translator training programs". Pym [23] identified the skills required for translation work in the age of integration of data from statistical machine translation into translation memory suites.

\section{Discussion and Conclusion}

The present study collected 652 bibliometric recordings from WOS Core collection database ranging from 2011 to 2020. VOSViewer and CiteSpace software were adopted to review these publications quantitatively and visually. This study is aimed to reveal the co-authorship relations, the trend topics, the most influential authors, journals and publications in the field of translation education.

As a result of the co-authorship analysis, it was found that the cooperation between the clusters formed by the authors working on translation education was weak. There were three major clusters including Soudabeh Nour, Helene Stengers and Esli Struys. The most productive author was Christian Olalla-Soler from University of Bologna with 8 documents.

As a result of the analysis of institution and country cooperation, Universitat Autònoma de Barcelona in Spain was the most productive institution, and Guangdong University of Foreign Studies in China was the nest. In terms of country collaboration, it was seen that there was a strong cooperation among countries including China, Spain, the UK and the USA.

The co-occurring analysis of keywords visualized by VOSViewer has provided detailed information about the literature of translation education. Based on the frequency of keywords, the hop research topics on translation education focused on: (a) translation; (b) translation competence; (c) language; (d) competence; (e) English. The emerging trend visualized by CiteSpace covered the following aspects: (1) translation practice; (2) implicit teaching; (3) translation competence; (4) intercultural competence; (5) interpreting.

In terms of TLS, the most 5 influential authors included Kiraly, D, Pym, A, Kelly, D, Beeby, A and Gile, D. Interpreter and Translation Trainer, Meta, Interpreting, Target and Perspectives were the most cited journals. Together with 
the most cited references, readers can get a quick glimpse into the field of translation education.

With these above results, researchers could grasp an overall knowledge of translation education to where to start their study, which reference to read, which journal to choose. They can also decide which topic to choose based on the trend analysis.

However, there are some limitations in this paper. First, the scope covered in this study is limited to English papers retrieved from WOS core collection database from 2011 to 2020 . Therefore, there is no information from other databases like Scopus and CSSCI. And a wide range of time span can be considered. Second, the analysis of research trends is not profound. Deeper analysis into this aspect is needed.

\section{Fund}

This work was supported by the Scientific Research Project of Hunan Provincial Department of Education [17C0449].

\section{Conflicts of Interest}

The author declares no conflicts of interest.

\section{References}

[1] Yan, Y., Xie, Z. and Chen, H. (2020) Industry Requirements for Translators across China before COVID-19: Analyzing 51job Listings through Web Scraping. Revista Argentina de Clínica Psicológica, 29, 768-779.

[2] Kasperavičienè, R. and Horbačauskienė, J. (2020) Self-Revision and Other-Revision as Part of Translation Competence in Translator Training. Journal of Language and Cultural Education, 8, 117-133. https://doi.org/10.2478/jolace-2020-0007

[3] Akbari, A. (2019) Measuring the Degree of Difficulty and Translation Competence: The Two Intertwining Variables in Modern Translation Multiple-Choice Items Testing. Journal of Applied Research in Higher Education, 12, 475-494. https://doi.org/10.1108/JARHE-11-2018-0248

[4] Loock, R. (2020) No More Rage against the Machine: How the Corpus-Based Identification of Machine-Translationese Can Lead to Student Empowerment. The Journal of Specialised Translation (JoSTrans), 34, 150-170.

[5] Olkhovska, A. and Frolova, I. (2020) Using Machine Translation Engines in the Classroom: A Survey of Translation Students' Performance. Advanced Education, 7, 47-55. https://doi.org/10.20535/2410-8286.197812

[6] Akdağ, A.I. (2019) Improving Motivation in Translator Training: Achievement Goal Orientations of Translation Studies Students. Selçuk Üniversitesi Edebiyat Fakültesi Dergisi, 1-14.

[7] Liu, C. and Yu, C. (2019) Understanding Students' Motivation in Translation Learning: A Case Study from the Self-Concept Perspective. Asian-Pacific Journal of Second and Foreign Language Education, 4, 1-19. https://doi.org/10.1186/s40862-019-0066-6

[8] Baker, M. and Maier, C. (2011) Ethics in Interpreter \& Translator Training: Critical Perspectives. The Interpreter and Translator Trainer, 5, 1-14. 
https://doi.org/10.1080/13556509.2011.10798809

[9] Khoshsaligheh, M., Mehdizadkhani, M. and Keyvan, S. (2017) Severity of Types of Violations of Research Ethics: Perception of Iranian Master's Students of Translation. Journal of Academic Ethics, 15, 125-140.

https://doi.org/10.1007/s10805-017-9277-y

[10] Beauvais, C. and Ryland, C. (2020) “We Actually Created a Good Mood!": Meta-Linguistic and Literary Engagement through Collaborative Translation in the Secondary Classroom. Language, Culture and Curriculum, 1-19.

https://doi.org/10.1080/07908318.2020.1809666

[11] Omar, A. and Gomaa, Y. (2020) The Machine Translation of Literature: Implications for Translation Pedagogy. International Journal of Emerging Technologies in Learning (iJET), 15, 228-235. https://doi.org/10.3991/ijet.v15i11.13275

[12] Heinisch, B. and Iacono, K. (2019) Attitudes of Professional Translators and Translation Students towards Order Management and Translator Platforms. The Journal of Specialised Translation, 32, 61-89.

[13] Omar, A., Khafaga, A.F. and Shaalan, I.E.-N.A.W. (2020) The Impact of Translation Software on Improving the Performance of Translation Majors. International Journal of Advanced Computer Science and Applications (IJACSA), 11, 287-292. https://doi.org/10.14569/IJACSA.2020.0110439

[14] Zhou, X., Li, T. and Ma, X. (2021) A Bibliometric Analysis of Comparative Research on the Evolution of International and Chinese Green Supply Chain Research Hotspots and Frontiers. Environmental Science and Pollution Research (International), 28, 6302-6323. https://doi.org/10.1007/s11356-020-11947-x

[15] Chen, C. (2006) CiteSpace II: Detecting and Visualizing Emerging Trends and Transient Patterns in Scientific Literature. Journal of the American Society for Information Science and Technology, 57, 359-377. https://doi.org/10.1002/asi.20317

[16] Hurtado Albir, A. (2015) The Acquisition of Translation Competence. Competences, Tasks, and Assessment in Translator Training. Meta, 60, 256-280. https://doi.org/10.7202/1032857ar

[17] Babcock, L. and Vallesi, A. (2017) Are Simultaneous Interpreters Expert Bilinguals, Unique Bilinguals, or Both? Bilingualism: Language and Cognition, 20, 403-417. https://doi.org/10.1017/S1366728915000735

[18] Gaspari, F., Almaghout, H. and Doherty, S. (2015) A Survey of Machine Translation Competences: Insights for Translation Technology Educators and Practitioners. Perspectives, 23, 333-358. https://doi.org/10.1080/0907676X.2014.979842

[19] Cai, R., Dong, Y., Zhao, N. and Lin, J. (2015) Factors Contributing to Individual Differences in the Development of Consecutive Interpreting Competence for Beginner Student Interpreters. The Interpreter and Translator Trainer, 9, 104-120. https://doi.org/10.1080/1750399X.2015.1016279

[20] Morales, J., Padilla, F., Gomez-Ariza, C.J. and Bajo, M.T. (2015) Simultaneous Interpretation Selectively Influences Working Memory and Attentional Networks. Acta Psychologica, 155, 82-91. https://doi.org/10.1016/j.actpsy.2014.12.004

[21] Davitti, E. (2013) Dialogue Interpreting as Intercultural Mediation. Interpreting. International Journal of Research and Practice in Interpreting, 15, 168-199. https://doi.org/10.1075/intp.15.2.02dav

[22] Kenny, D. and Doherty, S. (2014) Statistical Machine Translation in the Translation Curriculum: Overcoming Obstacles and Empowering Translators. The Interpreter 
and Translator Trainer, 8, 276-294. https://doi.org/10.1080/1750399X.2014.936112

[23] Pym, A. (2014) Translation Skill-Sets in a Machine-Translation Age. Meta, 58, 487-503. https://doi.org/10.7202/1025047ar 